\title{
THE PRODUCTION OF LAMMAS SHOOTS ON JACK PINE IN ONTARIO ${ }^{1}$
}

\author{
By J. B. THOMAS ${ }^{2}$
}

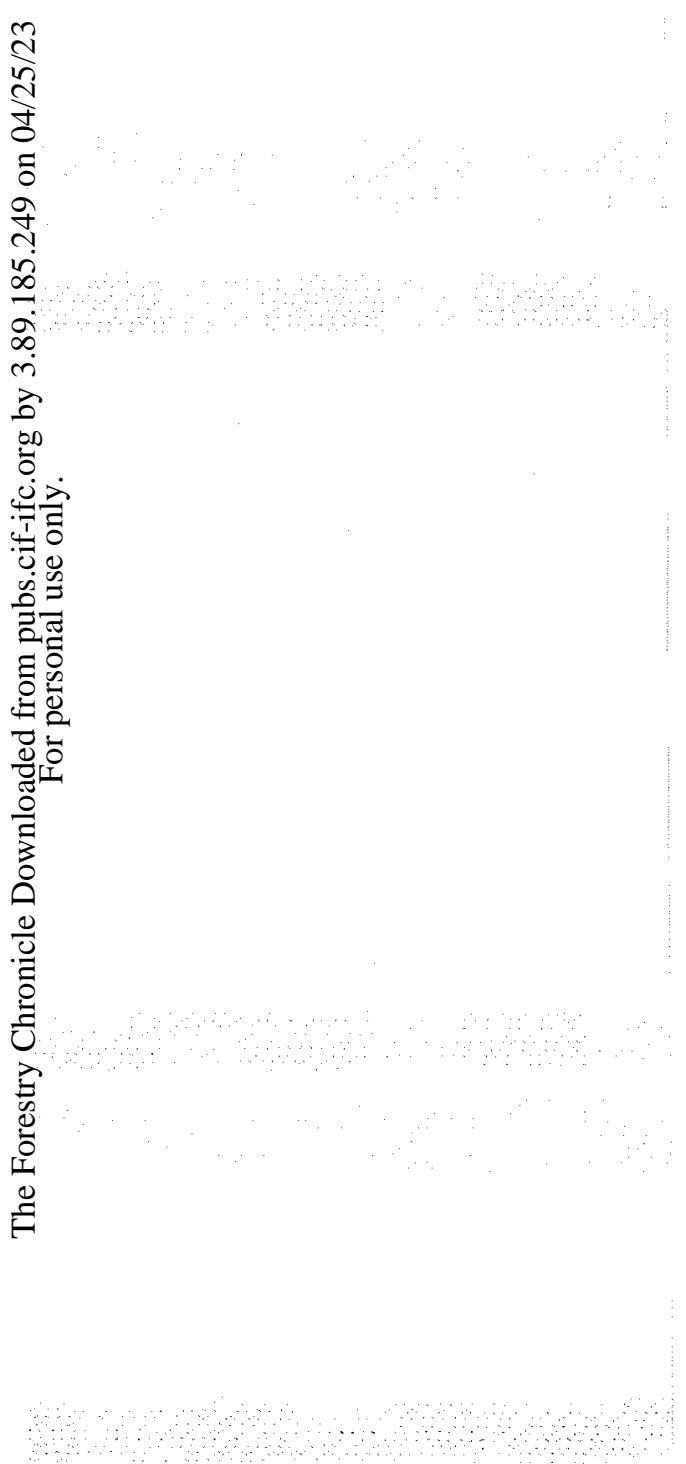

After graduation from the Faculty of Forestry, University of New Brunswick, in 1949, J. B. Thomas continued his interests in entomology at Macdonald College, McGill University. He received his M.Sc. in 1952 and Ph.D. in 1954 in entomology. His chief interests at present are in studies of bark beetles.

In mid-July, 1955, an unusual growth condition was noticed on jack, white, red, and Scots pine reproduction in the Lake Nipigon region of Ontario. Many lateral and some terminal buds set for 1956 broke dormancy, and new shoots from 1 to 6 inches long were produced. On these, new terminal and, in most cases, new lateral buds were set. This phenomenon was also observed at a number of points from Kenora in northwestern Ontario east to St. Williams in southern Ontario.

Büsgen, Münch and Thomson (1929) described this type of extra-seasonal growth on certain hardwoods and conifers in Europe as "lammas" shoot growth, the name being derived from the time of year at which it appears. In the United States, Jump (1938a, 1938b) investigated the forking caused by the development of lammas shoots on the main stems of red pine in plantations in New York State, showing that failure of the two sides of the fork to unite solidly permitted the entrance of fungal spores. More recently, Carvell (1956) and Littlefield (1956) have reported lammas growth on red pine planted in West Virginia and New York States, respectively. Carvell estimated that 76 per cent of the trees with lammas shoots had two or more strong leaders the next year capable of producing a permanent fork in the tree, thereby lessening its value for lumber.

Lammas growth was most prevalent on jack pine in the Lake Nipigon region, the stems illustrated in Fig. 1 being typical of the various conditions encountered in late September, 1955. One or more of the lateral buds around the terminal of the two shoots in Fig $1 \mathrm{a}$ and $1 \mathrm{~b}$ developed, but the terminal buds only swelled slightly and a few needles protruded from the sheath. The terminal as well as three laterals of the shoot in Fig. 1c elongated, whereas only the terminal elongated in the shoot illustrated in Fig. 1d.

It was thought at first that repeated production of lammas shoots on young trees might have caused or at least contributed to deformities in jack pine reproduction being investigated at that time. Observations were continued, therefore, in the Lake Nipigon region during the 1956 growing season on

${ }^{1}$ Contribution No. 432 from the Forest Biology Division, Science Service, Department of Agriculture, Ottawa, Canada. Received for publication November 22, 1957.

Research Officer, Forest Insect Laboratory, Sault Ste. Marie, Ontario. 
trees in which various types of lammas growth had been tagged and described in the autumn of 1955. During 1956, in all but a few instances, however, the terminal of the main axis retained dominancy over laterals that had put on extra growth (Figs. 2 and 3). In a few instances a fork did develop, particularly in those trees in which one or more laterals, but not the terminal, had 5 or 6 inches of lammas growth (Fig. 4).

Büsgen et al. (1929) stated that "Lammas shoots do not appear to be associated as a rule with a doubling of the annual ring"; but at the same time they reported at least one exception. The conditions reported in this paper would appear to be a further exception since all stems examined had two growth rings in 1956 in portions where lammas growth occurred in 1955, the inner ring representing the lammas growth of 1955, and the outer, the 1956 growth. No comparison was made of cell structure of lammas and normal growth but, as far as the number of growth rings was concerned, cross-sections of stems including 1955 lammas growth and 1956 growth were indistinguishable from similar sections through stems with normal 1955 and 1956 growth. In shoots in which there was only one bud set on the end of the 1955 lammas growth, or where more than one bud was set but only one developed, the others sloughing off, there was little or no external evidence of where the lammas growth stopped and normal 1956 growth began.

While the occurrence of lammas growth had a serious effect on the form of only a few trees, it could, of course, lead to later errors in estimating the year of origin of particular shoots. This is illustrated in Figs. 2, 3, and 4.

\section{ACKNOWLEDGEMENT}

Photographs were taken by Mr. D. C. Anderson of the Forest Insect Laboratory, Sault Ste. Marie, Ontario.

\section{REFERENCES}

BUSGEN, M., E. MUNCH, and T. THOMSON. 1929. The structure and life of forest trees. Chapman and Hall, Limited, London.

CARVELL, KENNETH L. 1956. Summer shoots cause permanent damage to red pine. J. For. 54: 271 .

JUMP, J. A. 1938a. A new disturbance of red pine. Science (n.s.) 87: 138-139.

JUMP, J. A. 1938b. A study of forking in red pine. Phytopathology 28: 798-811.

LITTLEFIELD, E. W. 1956. More on late seasonal growth of red pine. J. For. 54: 533.

\section{CAPTIONS FOR OPPOSITE PAGE}

Lammas shoot growth of jack pine. Leaders of young trees cut in September, 1955: a. one lateral shoot only; b. all lateral shoots, terminal bud swollen only; c. terminal and three lateral shoots; d. terminal shoot only, lateral buds slightly enlarged. (Needles have been removed from the lower portions of the stems.)

FIGURE 2: Lammas shoot growth of 1955 of the terminal only (AB). Top of young jack pine cut in September, 1956.

FIGURE 3: Lammas shoot growith of 1955 of the terminal $(A D)$ and four laterals (AB, $A C$, AE, AF). Top of young jack pine cut in September, 1956.

FIGURE 4: Lammas shoot growth of 1955 of one lateral only (AB). Top of young jack pine cut in September, 1956. 

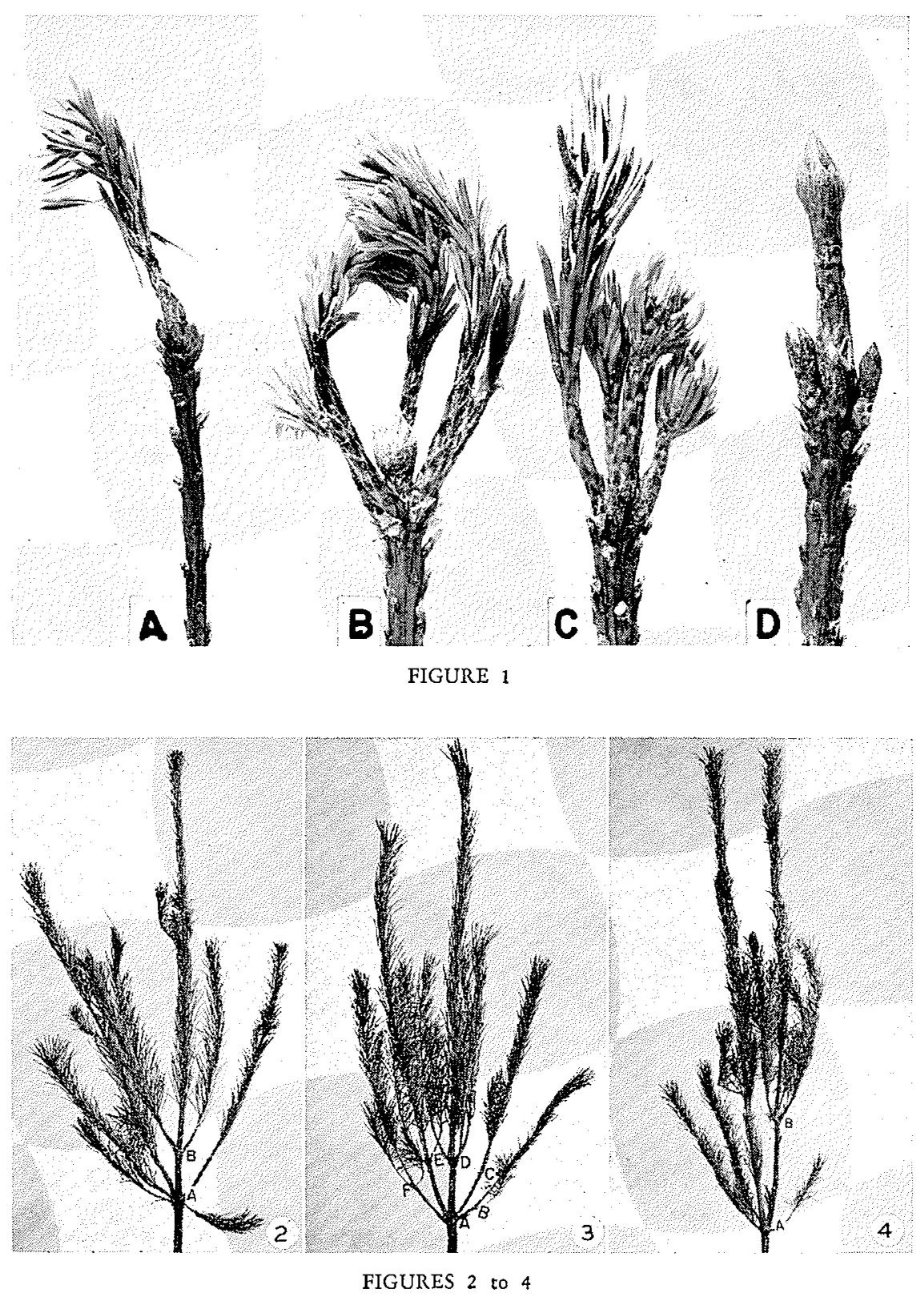